\title{
A Qualitative Study of Technology Integration into Culture and Sustainability in Schools
}

\author{
Marie-Anne Mundy and Lori Kupczynski \\ Department of Educational Leadership and Counseling, Texas A\&M University-Kingsville, 700 University Boulevard, MSC223, \\ Kingsville, TX 78363, USA \\ Correspondence should be addressed to Lori Kupczynski; kulpk000@tamuk.edu
}

Received 8 February 2013; Accepted 19 March 2013

Academic Editors: T. Carvalho and C. Dunst

Copyright (C 2013 M.-A. Mundy and L. Kupczynski. This is an open access article distributed under the Creative Commons Attribution License, which permits unrestricted use, distribution, and reproduction in any medium, provided the original work is properly cited.

\begin{abstract}
Despite overall increased access to technology both in and out of the classroom, technology is often still not being used to support learning and instruction in a meaningful manner. Teachers need to be helped to change the way they teach rather than just how to use computers. The TeachUp! Program was designed by Digital Opportunity Trust to improve the use of technology in day-to-day teaching activities through the use of interns who are present in the schools as a continuous support system and who provide an informal professional development. Interns examine types of technology available and how it can be utilized as a part of the design and implementation of the curriculum to extend the existing student knowledge and learning. Purposive samples from two school districts in southern Mississippi were selected to be interviewed on their perceptions of the integration of TeachUp! technology empowerment into the ongoing culture and operation of the schools, long-term systematic change, and improvement in education outcomes. According to the respondents, the TeachUp! Program has had a major sustaining effect on the respective school systems in these areas. The climate of the learning environment has evolved into a true 21st century learning organization with an increase in the use of technology.
\end{abstract}

\section{Introduction}

The plight of the modern 21st century student is extremely different from that of students of previous generations. Gone are the days of card catalogues, microfilms, and unaided, unadorned lectures. Even the introduction of slides and televisions into classrooms left education relatively the same [1]. Students in today's classrooms were brought up learning their letters and numbers from interactive LeapFrog LeapPads rather than paper and glue books. Today's K-12 student population represents the first generations to have been raised on technology in every aspect from communication and entertainment to information gathering [2]. Unfortunately, for the most part, the only place technology has not inundated these generations of "digital natives," those raised on technology, is the classroom [2]. This lack of technology in the classroom may actually be a disservice to digital natives as their experiences with technology have fundamentally changed their thinking patterns from those of "digital immigrants," previous generations who were not raised on technology [2]. Unfortunately, despite overall increased access by digital natives and digital immigrants to technology and computers both in and out of the classroom, technology is often still not being used to support learning and instruction paradigms that are believed to be the most beneficial for the student [3]. Ultimately, the necessary educational cultural shift necessary to appropriately utilize technology in a meaningful manner begins with the teacher as an agent of change [3, 4]. However, appropriate and sustainable professional development aimed at helping teachers to change the way they teach rather than just how to use computers in necessity to create a technological environment in which technology is used to create the deep and connected knowledge that is necessary for the 21st century [3].

In an effort to assist teachers in the adoption of technology beyond methods that support lecture-based instruction, the TeachUp! Program was designed by Digital Opportunity 
Trust (DOT) to empower teachers and improve educational quality. The TeachUp! Program improves teacher and administrator confidence and use of technology in day-today teaching activities through the use of TeachUp! interns. TeachUp! interns are placed in the schools and are present as a continuous support system or "safety net" to assist teachers and administrators as they begin to step out of the traditional and into the new and innovative. This embedded informal professional development allows teachers to take control of their learning and reflect on their practices and share with colleagues in a beneficial manner [5]. Additionally, the TeachUp! program removes lack of technical support from being a barrier [4]. According to the TeachUp! website, interns are recent college graduates who undergo an intensive training program before being placed in communities. During this training program, the interns learn to be facilitators, coaches, mentors, communicators and technology gurus [6]. Educational and instructional technologies and usages include self-directed drill and practice, online training, testing, interactive learning software, instructional delivery augmentation (i.e., video clips, smart boards), communication, publication, and Internet-based information accessing [4].

The sustainable introduction of technology into the educational setting requires, to some degree, change in beliefs, attitudes, and pedagogical ideologies, content knowledge, and pedagogical knowledge of instructional approaches, methods, strategies, and practices [3]. In general, research has shown that teachers are hesitant to adopt curricular or instructional innovative changes [3]. Technological changes present unique challenges due to their own constantly changing nature which leaves many teachers feeling uncomfortable with technology due to their own personal lack of knowledge, existing attitudes concerning technology and low self-efficacy [3]. In studies which have examined the differences between teachers who use information and communication technology (ICT) extensively and those with nonextensive usage, ICT self-efficacy and competency were identified to be major factors [7]. Additionally, the traditional school structure can often limit or constrain individual teacher's efforts to adopt technology in new ways [3]. It is important that technology integration be a school wide effort reflected in teacher and administrator attitudes as well as school policies and links to the wider community $[4,8]$. Research has repeatedly shown that a school's ICT vision is integral to effective, appropriate, and sustainable ICT integration [4].

An additional problem central to utilizing technology not just as a lecture aid, but as a true ally in education that can deepen knowledge, is integrating technology into the existing theoretical foundations of education [1]. Namely, examining what types of technology are available, how can they be used in a specific subject and then utilizing that technology as a part of the design and implementation of the curriculum, not just for the sake of using technology, but to extend the existing student knowledge and learning [1]. Professional development aimed at increasing technological pedagogical content knowledge has led to more conscious, strategic, and varied student centered learning activities and a more deliberate and judicious use of technology due to raised standards of quality [9].
Student knowledge and learning require students to be engaged in the learning process [10]. Unfortunately, by the time students enter into high school more than half report not taking their studies seriously [10]. Student disengagement has been related to disruptive and uncooperative student behavior, lost instructional time, low academic achievement, and school failure [10]. Modern students require a sense of autonomy and a sense of the relevance of course content in their lives for them to take an active role in their learning [10]. Furthermore, teaching and education must meet the student's developmental, intellectual, and social needs in order to foster the atmosphere for student achievement [10]. ICT can be central to this as it allows students to learn in an active, self-directed, and constructive way, if the teaching process is transformed in an appropriate manner [4]. ICT can engage students through independent self-paced learning, thinking, problem solving, reasoning behavior, and decision making [4]. These skills are important not just for classroom learning, but also for life-long learning, which is a central characteristic of effective teaching [7].

Ultimately, for the sustainable and appropriate adoption and integration of technology necessary for the engagement and success of 21 st century digital natives, school policies and the attitudes of administrators and teachers must allow for the new technology paradigm shift to take place [4]. This shift requires teachers to have appropriate professional development and the continued support necessary to increase relevant knowledge and self-efficacy which is integral to technology integration [3].

\section{Methodology}

For the purposes of examining the TeachUp! Program as an effective means of achieving the goals of student achievement through improved use and integration of technology, a qualitative assessment was completed by two school districts in southern Mississippi. Purposive samples of employees affected by the TeachUp! program were selected to be interviewed on their perceptions of the integration of TeachUp! technology empowerment into the on-going culture and operation of the schools, long-term systematic change, and improvement in education outcomes. The following employees were interviewed: technology director; high school and elementary principals; high school English and science teachers; middle school librarian, Math and alternative education teachers; and elementary music and special education teachers.

\section{Results}

3.1. Culture. It appears the TeachUp! Program has had a major sustaining effect on the respective school systems in these areas. One of the selected participants was a technology director, a district level employee, who was involved with the program. According to the technology director, the 21st century school project would not have been as successful without the involvement of DOT and the TeachUp! Program. The climate of the learning environment has completely evolved into a true 21 st century learning organization. The 
confidence level of the teachers and staff in regards to using technology grew and, therefore, enabled them to more confidently use technology in their lessons as more than a method of lecture enhancement.

The high school principal stated that the TeachUp! Program brought a more focused attention on the technology pieces that could be used instructionally. He perceived that it was an eye opening experience for the teachers to see that, in addition to their Promethean boards and Cisco phones, there were a number of other tools out there that they could use instructionally to help engage the students in a way that meets their developmental, intellectual, and social needs. It helped create a bridge between the students who are digital natives and the teachers who are digital immigrants. An English teacher indicated that the students have also become more comfortable using technology. The biggest change was the year the intern worked with the English and Biology teachers, teaching them how to integrate Promethean technology into their classes, how to unify technology and teaching and make technology a part of instruction in the classroom. Whether the teachers had Promethean boards, or InterWrite boards, the intern was able to meet the needs of all the departments at the school with training focused on all these types of technology. An alternate education teacher stated that without a doubt, the culture in their school had changed. As an example, when studying insects, a teacher can find a 30 -second to 1-minute clip that shows a bug in the process of doing something, which appears to engage the students through visual stimulation more than just the teacher talking would under traditional lecture circumstances. Technology is an attention getter and keeps students focused and engaged. A high school librarian felt that technology made teaching both easier and more versatile. As technology has made video clips easier to obtain and more accessible, teachers are more willing to use these clips and students are more engaged.

An elementary school principal has found an increase in the use of technology on the part of the teachers and an increase in student engagement. This was accomplished through the availability of the intern which made a difference to the teachers by providing a comfort for them; the teachers no longer felt alone in learning the new technology. Communication changed, as it was standardized through the Cisco phone or email system and communication increased. There was more of an effort to share strategies that utilized technology. An elementary teacher stated that during and after the program, basically everything changed in terms of technology use, namely, no more overheads. Rooms have chalkboards, but they just are not used anymore. "I cannot imagine going back to the way it was before." Approximately $80 \%$ of instruction now utilizes technology. "In my room I use technology as much as I can and as often as I can just because I do not see why you would not."

At the middle school, the culture of what happens when teachers need to be out of the classroom has changed. For instance, one teacher was able to Skype with a class whose teacher was away through an Algebra 1 period and taught both classes at the same time. Students in both classrooms were able to interact and learn together with no loss of instructional time.
3.2. Changes in School Operations. The technology director indicated that before the TeachUp! Program the schools used technology sparingly and did not view it as an integral part of their daily activities. As the program was introduced their knowledge level grew and, subsequently, their comfort level and they began utilizing the technology for more than just an occasional activity. Now, because of the program, teachers are $100 \%$ dependent on technology integration. It is used every day in every class setting. An elementary principal appeared to agree to this, stating that approximately 50 percent of instruction time was spent on technology before the program, but that increased to $100 \%$ with the event of a Promethean board in every classroom.

Not only computers were considered in the discussion of technology. Several teachers mentioned the telephones in the classrooms. Telephones have increased communication amongst teachers, between teachers and administrators, and between teachers and parents. In one of the schools, they are now able to use the bells and the announcements through the phones. The phone system really changed the way people are contacted. "As math department chair, I would use the phone system for department meetings. Everybody was able to stay where they were and we could all conference call at one time and that was nice." School operations, including much of the information concerning faculty meetings, are now done through emails or PowerPoints. Faculty can view the information at separate places; the school has become more virtual and more efficient.

3.3. Instructional Technology. According to the high school principal, before the TeachUp! Program approximately 30 percent of the teachers used instructional technology. These were the teachers who were most comfortable with it. During the time that the intern was in the school, it increased to about 70 percent, but now some type of technology is used daily whether it is the Promethean board or active votes in just about every classroom. One of the elementary principals reported that technology use moved from $50 \%$ before the program to $100 \%$ after the program. One of the elementary teachers indicated that before the program possibly only $10-$ $20 \%$ of instruction time was spent on technology; during the program this increased to over $50 \%$. Now, since the interns, technology has been incorporated into the lesson plans and $90 \%-100 \%$ of instruction uses technology on various levels. Another elementary teacher suggested that technology was used $100 \%$ in some form, whether it be through use of the Promethean board, the computer, or IPods. In other words, these are now definitely technology savvy schools. The staff appreciates technology, understands it, and utilizes it to the students' benefit now that the paradigm shift has taken effect and the attitudes of the teachers have changed due to the TeachUp! Program and interns.

The elementary principal asserted that the program had moved them towards having more technology-based instruction - teachers being able to provide more engaging learning opportunities for the students and understanding how to use the available technology. An elementary teacher said: "You cannot imagine teaching without the computer anymore. It is just a given." An elementary special education teacher also 
stated that they would be lost without it. For instance, she has used the computer to teach syllables for the alternate assessment, which is the state test, and has found that students remember it better because they can see it with a picture, a type of cognitive learning strategy. Syllables were learned and the students loved it.

A math teacher at a middle school stated that before TeachUp!, the overhead projector was the outdated technology used to present information to the class. Since the TeachUp! Grant, the Promethean board is used $100 \%$ of the time. All of her classes now use the interactive calculator with the interactive board and all her lessons are planned so that her students work on the board daily and are active participants in their learning.

3.4. Sustainability. When questioned about sustainability, the technology director noted that technology was now being used daily in the classrooms. The high school principal suggested that sustainability has been reached because one of the tenets of the program was to train people so that they could carry it on. The faculty are now assisting one another, both suggesting how to incorporate technology into lesson plans and giving on-site instruction. According to an English teacher, the faculty are more comfortable using technology and student engagement has definitely increased. For the average teacher before the program, the Promethean board or smart board was used as a glorified projector; now it has become an interactive tool that is being used on an everyday basis.

At the high school, there have been some systemic changes. Teachers are meeting together around incorporating the use of technology into their classes. The Teach-Up! teachers are training new teachers with the technology that they learned from the DOT intern. According to the principal, "It is almost like a seamless process now where we are able to work with our people around the things that we were taught." This represents true sustainability.

An elementary recounted several technology processes that have been enhanced and have continued to be in place since the program began, including a school website, the use of the Promethean board, and the use of the computers in the classroom. In addition, instruction utilizing web-based tools such as Skype and creating newsletters is now quite common. Communication with parents via newsletters has increased. A Promethean board is in place in the auditorium where visual information is displayed for the parents. A computer lab has been opened for parents to come in and work on projects with their children. On family read night the parents come and create their reading fair board projects with students on the computer, or they have laptops in the classroom for them to work on. At one elementary school, every time the school year changes, they review the best practices of using the technological equipment and discuss how it is used.

3.5. Students Use of Technology. The technology director reported that $100 \%$ of the students are now using technology in the classroom. At the high school, the principal approximated $70 \%$ of the students used technology on any particular day. The students now use cell phones in class for academic work; for instance, students in an English class may be asked to research a certain piece from Macbeth on their phone. The English teacher looked at the question of students use from the angle of the teacher. She stated that before the program only about 60 percent of the classes had access to interactive boards, but most teachers did not know how to use them. But now she feels that the teachers cannot live without tools such as the interactive boards and clickers. According to her, if the teachers are using technology in the classroom on a daily basis, then so are the students.

An elementary principal affirmed that students are on the computers daily at the computer station. They also use the Promethean board as one of the learning centers, students have a computer lab they can use as a whole class, and the school also has an intervention lab. Another elementary principal confirmed this stating that $100 \%$ of their students use technology and there is not one student that does not use it as it has been built into instruction for students. An elementary teacher stated that $100 \%$ of her students use the computers: "we have one group doing IPods for math during the tiger time. And of course the IPods are used in the other classes for all kinds of things. It is all over the place. We use it in the gym, we use it everywhere."

An enlightening comment about students' use was given by a science teacher at the high school who indicated that 100 percent of their students now used technology. Before the intern arrived, they had technology, but did not know everything that it could do. The intern at their school was able to integrate not only using the Promethean board but also different things that you could do with a smart board. These skills were sometimes things that the students knew how to do, but the teachers did not.

At the middle school, all the students use technology one way or another in the math classroom. Every one of them uses calculators that can be linked, and the teacher can view what students are doing on their calculators on a daily basis. About $20 \%$ of students' time is spent on computers researching information on the internet or using an online program. At some point, everyday, students use technology.

It appears that faculty who worked directly with interns still feel very strongly about the effects of the program and in particular the effects of the interns. Below are some reflections.

"At the time when our intern was here I was an instructional technologist at the high school, and he was a huge help to me. The intern was actually assigned to me and through me I was able branch him out to other teachers. Our intern came into the school and found technology that we already had at the school and showed us how to use the technology that we already had here that was being underused or not used at all. He not only worked with the teachers at the school, but he also worked with the counselors and the principal. At the time our intern was here, our counselors had to use a new spreadsheet management program, and he really helped them learn how to navigate and 
utilize the program. The new spreadsheet management program was something that had major impact on our school, because it was something that affected state test rosters. To this day our head counselor still speaks fondly of him, and for him to impact state testing was something that was so big. Our tech people here really appreciated him as well because a lot of the time they were not as comfortable with the software as they were the hardware, and our intern was able to come in and train us on the software. Hattiesburg High is a huge school and we had all these IP phones and other technology floating around that was not being used to its full potential. Our intern came in and really made a difference in the way we were using technology, and in the process he became like one of the faculty. He would sometimes attend faculty meetings and made himself available at any time the teachers needed help."

"When the Promethean boards came about, the digital time clock system, the phone systems in every classroom, the display in the foyer of the slideshow that we have of students interacting with staff and parents as a greeting opportunity, the security features that are in place all over this school, the camera system, security gate, it all changed the culture of the school tremendously. It made the building safer, made the environment more engaging. It provided for more efficiency for staff as a whole."

"We had an elderly teacher that had been here a long time when our intern first arrived, and she was scared of the promethean and did not want anything to do with it. After our intern was here at the school for a while I would see her in the classroom using clips on the board in her lessons. To me, that definitely shows that there was an impact made."

"If we are not having them do something with the promethean board or response pads, they use their cell phones to answer questions that we have displayed. Also, with using the response pads or interactive pieces on the promethean board we are getting some kind of feedback at that moment in time from the students. This helps us to know whether we need to continue on with the lesson or spend more time on the subject that the question was pertaining to."

"I would say before the intern was here the most technology I used was PowerPoint. There was no response pad or creative flip chart to make things interactive for the students. Now I can teach the anatomy of the cell and students can actually go to the board and move parts of the cell to match the correct term. I was even introduced to a website by the intern that showed me flip charts that were already established that I could use. I would say that for me the amount of time changed dramatically while the intern was here. Sometimes our tech people were not always available, but with the intern he was always willing to come in and help and could answer questions right when I had them. Did we use some technology before? Yes. But now we know how to use it more effectively, and it is something that we use every day."

"It makes learning not only fun for them but for us too. We get so excited about the way lessons and activities are going to look when the students see them. It started out as just syllables in a PowerPoint, and we wound up doing similar activities the whole school year, and I just pulled in more things. It made teaching a lot easier. Before the program, I was not here at this school, but being from a different school and then coming here it was a world of difference. Daily they are using technology."

\begin{abstract}
"The interns were helpful in the classroom managing the equipment that we had. They were very useful in teaching us how to do things and making sure everything was done correctly. The only time I ever utilized the intern was that way. Sometimes I had direct contact with the intern, and sometimes I learned things from other teachers that worked with the intern, so we shared knowledge. The materials themselves were truly wonderful. In my math class, I used them every day. The activware software, the Promethean planet, the Activotes, the slate, all of that stuff we utilized every day. Videoing in our classes and then playing it back was an example. When I was out for a week, I actually videoed my lessons for the week I was going to be out. Using the materials that we had I was actually able to teach the lesson while I was not there."
\end{abstract}

\section{Conclusion}

According to the respondents, the TeachUp! Program has proved to be successful in all the areas studied. Before the TeachUp! Program, the schools used technology sparingly and did not view it as an integral part of their daily activities. As the program was introduced, their knowledge level grew and, subsequently, their comfort level and they began utilizing the technology for more than just an occasional activity. Now, teachers are $100 \%$ dependent on technology integration and are now assisting one another, both suggesting how to incorporate technology into lesson plans and giving on-site instruction. This represents true sustainability. In addition, all students are now using technology in the classroom. It appears that faculty who worked directly with interns still feel very strongly about the effects of the program and its interns.

The use of interns as a "safety net" removes several large barriers to technology adoption in schools such as teacher 
comfort and lack of technical support [4]. Through the removal of these barriers, overall cultural change becomes possible as teacher and administrator attitudes begin to shift and allow for an overall paradigm shift $[3,4]$. This paradigm shift, in turn, makes for sustainable and effective classrooms and teaching strategies that engage modern students in enhanced thinking activities which ultimately lead to success $[4,7]$.

\section{References}

[1] P. Rodríguez, M. Nussbaum, and L. Dombrovskaia, "ICT for education: a conceptual framework for the sustainable adoption of technology-enhanced learning environments in schools," Technology, Pedagogy and Education, vol. 21, no. 3, pp. 291-315, 2012.

[2] M. Prensky, "Digital natives, digital immigrants Part 1," On the Horizon, vol. 9, no. 5, pp. 1-6, 2001.

[3] P. A. Ertmer and A. T. Ottenbreit-leftwich, "Teacher technology change: how knowledge, confidence, beliefs, and culture intersect," Journal of Research and Technology in Education, vol. 42, no. 3, pp. 255-284, 2010.

[4] M. Afshari, K. A. Bakar, W. S. Luan, B. A. Samah, and F. S. Fooi, "Factors affecting teachers' use of information," International Journal of Instruction, vol. 2, no. 1, pp. 77-104, 2009.

[5] D. Richter, M. Kunter, U. Klusmann, O. Lüdtke, and J. Baumert, "Professional development across the teaching career: teachers' uptake of formal and informal learning opportunities," Teaching and Teacher Education, vol. 27, no. 1, pp. 116-126, 2011.

[6] Digital Opportunity Trust, TeachUp!, October 2012, http:// www.dotrust.org/programs/teachup.

[7] J. Voogt, "Teacher factors associated with innovative curriculum goals and pedagogical practices: differences between extensive and non-extensive ICT-using science teachers," Journal of Computer Assisted Learning, vol. 26, no. 6, pp. 453-464, 2010.

[8] N. Law, M. W. Lee, and A. Chan, "Policy impacts on pedagogical practice and ICT use: an exploration of the results from SITES 2006," Journal of Computer Assisted Learning, vol. 26, no. 6, pp. 465-477, 2010.

[9] J. B. Harris and M. J. Hofer, "Technological pedagogical content knowledge (TPACK) in action: a descriptive study of secondary teachers' curriculum-based, technology-related instructional planning," Journal of Research and Technology in Education, vol. 43, no. 3, pp. 211-229, 2011.

[10] J. P. Allen, R. C. Pianta, A. Gregory, A. Y. Mikami, and J. Lun, "An interaction-based approach to enhancing secondary school instruction and student achievement," Science, vol. 333, no. 6045 , pp. 1034-1037, 2011. 

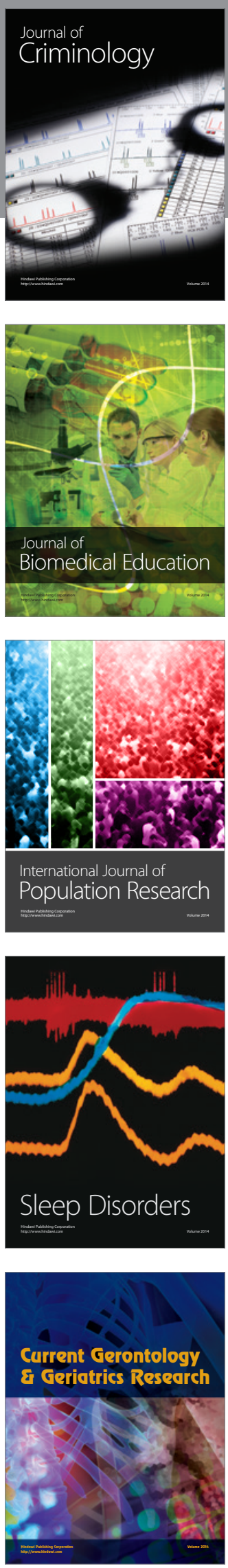
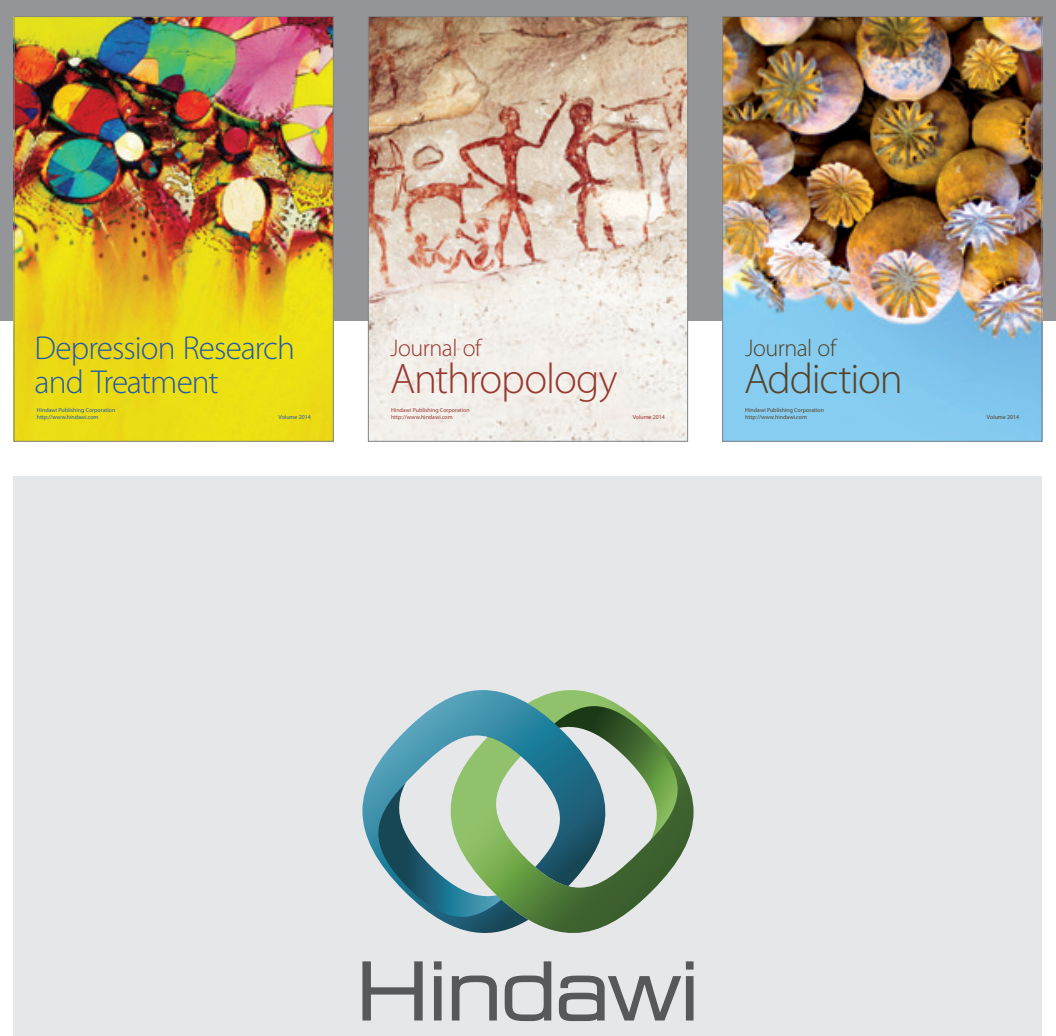

Submit your manuscripts at

http://www.hindawi.com

Child Development Research
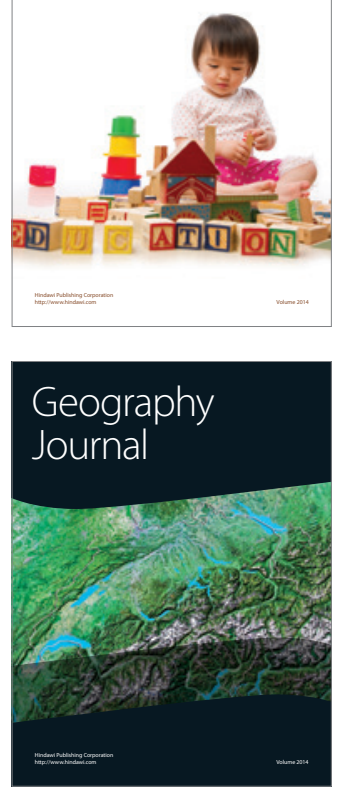

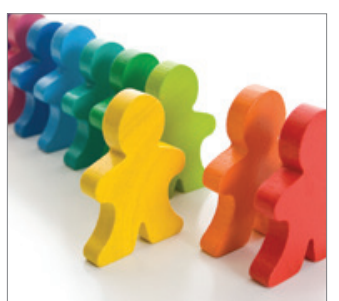

Autism

Research and Treatment
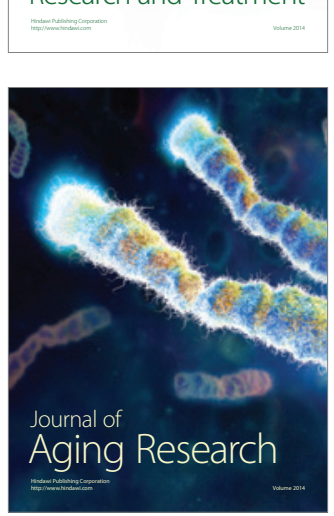
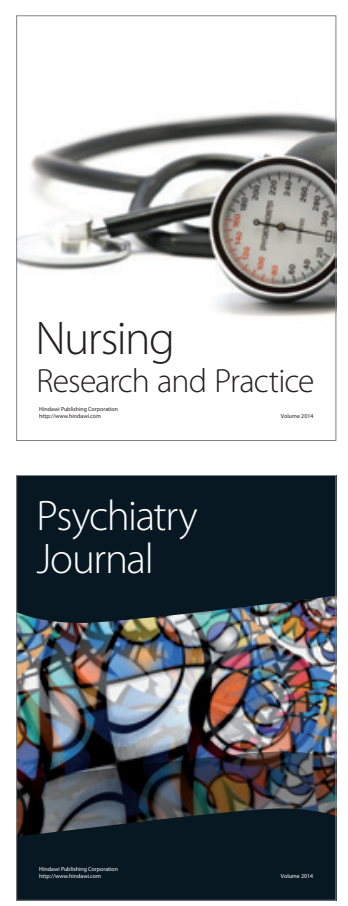
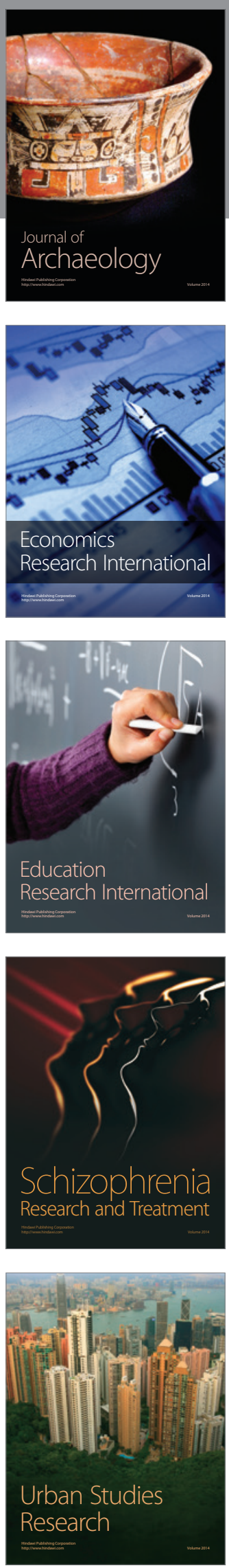